\title{
Cultivating Self-Awareness with Team-Teaching: Connections between Classroom Learning and Experiential Learning
}

\author{
Denise M. Polk, Ph.D. \\ Associate Professor, Department of Communication Studies \\ West Chester University \\ West Chester, PA 19383 \\ 610-436-2658 \\ FAX: 610-436-3046 \\ dpolk@,wcupa.edu
}

\begin{abstract}
The Honors College program prepares leaders for the $21^{\text {st }}$ century to become forces for positive change through problem-solving, scholarship, service, teamwork, and leadership. Its structure involves nine sequenced courses familiarizing students with challenges facing communities. Courses are team-taught by professors in different disciplines to highlight the diversity in applying concepts across contexts. This paper offers an examination of the connections for cultivating self-awareness through team-teaching in the classroom and experiential learning.
\end{abstract}

\section{Introduction}

Research is the "tool to tell our story in a way that highlights our relevance as we work to build positive relationships and offer opportunities for real self-discovery through experiential education" (Bialeschki, 2007, p. 368)

What does a kinesiology professor have in common with a communication studies professor? It sounds like the set up for a joke, but in actuality they share a course. Two professors in different academic colleges at a midsize university share the same 46 students each fall, setting out to make meaningful connections between their approaches to leadership development. The purpose of this paper is to introduce a holistic approach to leadership development involving selfawareness using experiential education in both classroom and adventure-based learning environments. The course Self-Awareness and Development is the first in a nine-course sequence for an Honors College focused on leadership.

College is associated with self-growth and self-discovery. Developing self-awareness positions individuals to understand and implement theoretical components of leadership (Buller, 2008). Self-awareness focuses attention inward (Mead, 1934) and refers to the capacity to identify, process, and store self-information (Duval \& Wicklund, 1972). It means having a deep understanding of one's emotions, strengths, limitations, values, and motives (Goleman, Boyatzis, $\&$ McKee, 2002). It involves reflecting on perceptions and processing stimuli. More importantly, it helps people become neither overly self-critical nor naively hopeful (Goleman, et al., 2002). It is being honest with oneself about oneself. 
The importance of self-awareness is evident. The capacity for self-reflection is essential for a better future (Leary \& Buttermore, 2003). Moreover, heightened self-awareness produces effects across disciplines (see Carver, 2002; Silvia \& Duval, 2001; Wicklund, 1975, 1978), including leadership (Ashley \& Reiter-Palmon, 2012; Henck \& Hulme, 2008).

An underlying principle of the Honors course is that self-awareness develops through intrapersonal (i.e., reflection), interpersonal, and group interaction. Developing self-awareness is critical because increased understanding of self, others, and experiences facilitates effective leadership. Students must engage in purposeful, self-regulatory evaluation that results in interpreting, analyzing, judging, and making inferences about leadership. This process engages critical thinking, where students gain knowledge about themselves, others, and situations to develop as effective leaders.

\section{Benefits of Adventure-Based Learning}

Adventure education is one well-known experiential learning (EL) approach. EL is associated with intellectual development, cross-cultural and global awareness, civic and social responsibility, ethical development, and personal growth (National Society for Experiential Education cited in McClellan \& Hyle, 2012). Advocates of EL agree that, "People learn best by direct and purposeful contact with their learning experiences" (Priest \& Gass, 1997, p.17). Experiential education is a philosophy that allows a number of EL curricular projects to find a home underneath its conceptual framework (Itin, 1999). Adventure-based learning is one expression of that philosophy.

Kolb (1984) developed EL theory and defined it as a cyclical process whereby grasping and transforming experience creates knowledge. His model contains four elements:

- Concrete experience.

- Reflective observation.

- Abstract conceptualization.

- Active experimentation.

EL begins with experience followed by reflection, discussion, analysis, and evaluation of that experience. The process requires learners to conceptualize, synthesize, and integrate experiences. This impacts the way students view, perceive, categorize, evaluate, and seek experiences (Wright, 1970). Other necessary criteria include: personally significant learner goals, engagement, ongoing reflection, involving the whole learner, recognizing prior learning, concern for student well-being, and development of teacher-student trust, respect, and openness (Andresen, Boud, \& Cohen, 2000).

Goals for EL curriculum vary. They include instilling love of learning (e.g., Jiusto \& DiBiasio, 2006) as well as developing social skills, teamwork, and problem-solving (e.g., Garst, Scheider, $\&$ Baker, 2001). In addition, Outward Bound's (2013) mission is to inspire character development and self-discovery through challenge and adventure, to impel people to achieve more than they thought possible, to show compassion, and to better the world. Watching teams 
of Honors students, for example, help each other climb a 14-foot wall makes it clear that the adventure-based part of this course achieves such goals.

EL provides many benefits. Learners can engage in reflective observation, form abstract conceptualizations, and develop active experimentation (Hirsch \& Lloyd, 2005). Students learn about themselves and others (McClellan \& Hyle, 2012). Adult learning best occurs through experiential approaches; yet, traditional lecture formats predominate (Silverman \& Casazza, 2000). Traditional pedagogical approaches emphasize "acquisition, manipulation, and recall of abstractions" (Mitchell \& Poutiatine, 2001, p. 180), but Kolb (1984), Knowles (1978), and others suggested that individual-centered, multisensory, experiential, and collaborative lessons facilitate learning (Giddens, 1991; Schofield \& Caragata, 1999). Thus, EL illustrates complexities that cannot be created in traditional classrooms (Schlanger, Lengfelder, \& Groves, 1999).

\section{Benefits of Combining Approaches}

Leaders cannot develop exclusively through classroom knowledge (Roberts, 2008; West, 2012) because leadership development does not "just happen" by learning theory. Such courses are comparable to driver education that never places students behind the wheel (Nirenberg, 2003). Textbook learning and EL are opposite ends of a spectrum (Morrison, Rha, \& Helfman, 2003). Therefore, leadership skills best develop over time through programs integrating theory and practice while emphasizing reflective processes (Connaughton, Lawrence, \& Ruben, 2003). Students need more than knowledge and skills; they need to know how to be self-aware, to selfcritique, and to consider contexts and experiences (Tsang, 2010). Expanding curricular boundaries facilitates learners to position themselves in new territory (Miller, 2000). This teamtaught Honors course blurs learning environments with the belief that they can be mutually informative and transformational. This course is particularly important because it sets a foundation in their first semester that learning can positively violate students' preconceived expectations.

Nirenberg (2003) described a locus of leadership that begins with mastering oneself where students receive exposure to leadership techniques, skills, language, and rationales. West (2012) claimed mastering oneself is comparable to the undergraduate foundation described by Farr and Brazil (2009) and Drohan and Murray (2001) that emphasizes knowledge, experience, and reflection. The course outlined serves as the first course in such a program, combining theory and practice in both classroom and out-of-classroom experiences.

\section{A Philosophy of Leadership Development}

Wood (1977) identified significant shortcomings of leadership training and presented an alternative adaptive approach. Understanding the needs, desires, and expectations of group members directly impacts a leader's effective action. However, effective leaders also must understand situational constraints (Lippitt, 1961). Adaptive leading facilitates leaders to adjust behaviors and self-presentation appropriately (Wood, 1977) because leaders are sufficiently perceptive at analyzing unique situations and group members in relation to the goals, and they 
employ appropriate behaviors (Tannenbaum \& Schmidt, 1958). Similarly, Grace, Ebbers, and Kell (1996) discussed the 4-V Leadership Model. The four Vs are:

- Values (ego, self-awareness, and moral development; social perspective -taking; and service learning).

- Vision (campus and community leadership).

- Voice (communication skills and accomplishing goals).

- Virtue (commitment to the common good).

The four Vs are vital to adaptive leadership. Becoming aware of strengths and limitations of self and others must occur continuously. Increasing self-awareness helps leaders increase the congruence of values between leaders and followers, strengthening that relationship (Weierter, 1999). Thus, it is through self-awareness that individuals can identify what is most conducive to effective problem-solving.

In addition to increasing self-awareness, students must develop critical thinking skills. Critical thinking ought to be considered in the values portion of the 4-V Model. The need to think critically spans academic and professional sectors. For example, both faculty and industry experts cited critical thinking as the highest rated competency for college graduates (Maricle cited in Burbach, Matkin, \& Fritz, 2004). To become better critical thinkers, students need active practice in observing and evaluating what goes on inside and outside their minds and bodies (Lauer, 1990). Critical thinking development helps students know when to reject another leader's ideas in favor of promoting a minority viewpoint (Nemeth \& Owens, 1996). Consistently clear minority voices may change how groups approach problems (Brain, 2002). Thus, independent, creative, and divergent thinking can facilitate beneficial solutions.

Students come wired and hyperlinked to instant information; however, without critical thinking ability they cannot value and make sense of information (Clough, 2008). Self-knowledge, critical thinking, and the ability to live productively in a community are vital. Developing such skills requires effective interaction and thoughtful reflection upon consequences of interactions (Lauer, 1990). Lauer's statement shows how teaching critical thinking connects EL, traditional learning, and reflection to self-awareness to facilitate leadership development.

Critical thinking is applied philosophy, and philosophy drives students inward toward reflection (Harter, 2009). Reflection can focus on problem-solving or on increasing self-awareness. It occurs through formal and informal discussions, recorded thoughts, or contemplative practice (Clyde, Walker, \& Floyd, 2005; Rendón, 2009). Reflection helps individuals meaningfully connect their and others' experiences (Dewey, 1933). Through critical reflection, individuals identify and resolve differences between their values and experiences (Morton, 1993), grapple with complex problems (Schön, 1987), engage in identity development (Shain \& Farber, 1989), and increase critical thinking and cognitive development (Parks \& Millora, 2012).

Writing reflectively in journals is one pedagogical tool that facilitates information processing (Cisero, 2006; Mills, 2008), and critical thinking is grounded in reflection (Jones \& Brown, 1993). Journaling has been effective in many disciplines (Borasi \& Rose, 1989; Cook, 2000). 
Both the content and the process of reflection (i.e., giving space to think in a flexible, yet intentional manner) are important (Parks \& Millora, 2012). Furthermore, students perceive a deep connection between reflection and leadership experiences (White, 2012). The activities and assignments outlined below also use the other two Vs (e.g., vision and voice), setting a foundation that aligns with the Honors Program mission, which addresses the virtue of the 4-V model.

\section{The Case: Applying Self-Awareness in a Combined Adventure-Traditional Course}

The Honors College program prepares leaders for the $21^{\text {st }}$ century to become forces for positive change through problem-solving, scholarship, service, teamwork, and leadership. Its structure involves nine sequenced courses familiarizing students with challenges facing communities. Courses are team-taught by professors in different disciplines to highlight the diversity in applying concepts across contexts.

The first course is Self-Awareness \& Development. The description indicates students will focus on individual methods used to develop skills in physical, cognitive, emotional, and social aspects of their lives through a holistic approach including physical and mental aspects involving methods for the enhancement and maintenance of their strengths as well as approaches to risk taking. The objectives for the course are to:

- Show an increased sense of personal confidence and self-esteem including the ability to articulate a personal value system used in decision-making.

- Demonstrate support within the diverse community of the class.

- Demonstrate increased agility and physical coordination.

- Demonstrate increased joy in one's physical self and in being with others.

- Show risk-taking behavior.

- Demonstrate trust about physical and emotional safety with others through a graduated series of risk-taking activities.

- Create appropriate messages to communicate thoughts, feelings, and behaviors through activities which emphasize listening, verbal, and physical skills in group decisionmaking.

- Demonstrate cooperation and compromise through trial-and-error participation in a graduated series of problem-solving activities.

- Demonstrate skill in assessing and working effectively with strengths and weaknesses of group members to build upon acquaintance, trust, communication, and decision-making.

- Demonstrate persistence and resistance to frustration when attempting to reach a desired goal. (Schoel, Radcliffe, \& Prouty, 1989)

The issues that arise during activities often are not confined to a specific area of self-awareness. For example, although gender-related issues may arise more in one activity, no single activity is meant to address gender in leadership. Other topics include fear, compassion, and conflict. The purpose of classroom sessions is not simply to serve as a vehicle for discussing the adventure- 
based activities. Rather, whereas topics may relate to current or earlier activities, some topics impact students indirectly (i.e., coping with stress).

To engage students in self-awareness development, this course is designed to emphasize active learning methods (e.g., Meyers \& Jones, 1993) to facilitate cooperative learning. Cooperative learning is a form of active learning, taking place through students' interactions with their peers and environment (Adams \& Hamm, 1994; Tsay \& Brady, 2010). Cooperative learning builds self-worth, academic achievement, social skills and classroom equity (Johnson \& Johnson, 2009). The following assignments demonstrate the synthesis of leadership development by developing self-awareness, critical thinking, and effective communication.

\section{Journals and Reflections}

Levine (2007) wrote that youths' decisions should be informed by insights into personal strengths, weaknesses, and affinities. Cultivating reflective processes helps achieve these insights, and instructors have increasingly included time for reflection (Morton \& Campbell, 2007). Reflection is understood as a process during which individuals contemplate their experiences, perceptions, and roles (Ash \& Clayton, 2004).

Enduring transformations occur through reflection; they underpin the construction of new knowledge and perspectives from experiences (Mann, Gordon, \& McLeod, 2009). Reflective journaling also can improve critical thinking as well self-awareness and self-actualization (Maslow, 1979). It is particularly effective at stimulating critical thinking because students document observations, ask questions, speculate, develop self-awareness, synthesize ideas, and gain insights into problem-solving (de Acosta, 1995).

Reflection is a key component of deep learning which also emphasizes synthesizing information (Nelson, Laird, Shoup, Kuh, \& Schwarz, 2008). Reflection helps the students link experiences with learning objectives, while encouraging personal growth and understanding (McClam, Diambra, Burton, Fuss, \& Fudge, 2008). Thus, in addition to journaling about adventure-based activities, students write other reflections. For example, when covering the role of emotions on behavior, students write a letter to a friend or family member where they recount a conflict, their reaction and the emotions involved, and given the opportunity, what they would do differently with their heightened awareness of how emotions influence actions. In another assignment, students write an essay about a guiding core value and how it developed. Such assignments create space and time for linking experiences with learning objectives.

\section{Service-Learning}

The purpose of service-learning is to provide students with real-life community experiences. In a written reflection, students apply class concepts. This is important since Boud and Walker (1998) said that education should extend beyond theory by addressing knowledge gained from experience. Furthermore, Bowen's (1977) notion of citizenship calls for people to develop awareness about significant social issues and a disposition to participate in their communities. Recognizing and understanding one's role in society is central to this definition. Therefore, it is 
critical for students to participate in their community and to reflect on their role and responsibility to community.

\section{Presentations and Activities}

Traditional lecture formats typically are less effective than intensive practice (van Gelder, 2000). Obviously, adventure-based activities include intense experiences. However, the classroom portion also utilizes assignments geared at intensive practice. For example, students work in groups for one assignment. Groups receive different poems related to different class topics (e.g., courage). Groups develop and present an analysis of the poem in relation to the class topic, and they facilitate a discussion using their own questions and/or original activity. Such assignments match two elements of Johnson and Johnson's (2009) cooperative learning. The first is positive interdependence - students perceive their link to group members such that they cannot succeed alone. The second is individual accountability, where each student takes responsibility for completing assigned group tasks.

In addition, both instructors grade students on skill proficiency. In both adventure-based and classroom activities the students are evaluated on effective and appropriate peer communication, degree to which students actively worked to solve issues, attitudes toward activities and peers, and staying task-focused. Thus, the skill proficiencies incorporate and build on the other three essential elements of Johnson and Johnson's (2009) cooperative learning. These elements are face-to-face promotive interactions involving discussion and open communication, interpersonal communication, and group communication.

Having papers critiqued by instructors, group projects, and class presentations are related to critical thinking development (Tsui, 1999). Moreover, class discussions help guide in-depth thinking about course material, and they have been tied with critical thinking development (Keeley, Ali, \& Gebing, 1998). Group reflective discussion also may increase individual transformation by stimulating greater self-awareness, self-examination, self-reflection and confidence through dialogues with peers (Mann et al., 2009). Finally, student participation as well as peer and faculty encouragement and interaction relate positively to critical thinking (Smith, 1977). Therefore, these assignments facilitate opportunities for students to engage in developing self-reflection and critical thinking abilities. Students become what Giddens (1991) defined as the "reflexive project" (p. 32).

Higher education should facilitate learning through experience (McClellan \& Hyle, 2012). Whereas class-based knowledge is a vital component of learning, traditional lecture-based teaching is insufficient. This Honors course facilitates leadership development by focusing on reflection and critical thinking as integral to the course. This approach to self-awareness for leadership development applies the 4-V Leadership Model (Grace et al., 2012) to help the Honors College achieve its mission. Students see themselves in the center of their communities instead of at the top of a hierarchy (also part of virtue), creating the capacity for mutual influence. Likewise, blurring traditional curricular boundaries creates a learning environment that facilitates, as Miller (2000) stated, adult learners' ability to explore autobiographically and position them in new territory. "If we can find ways to identify and create learning experiences 
that... are truly significant, we will have made important progress in our effort to improve the quality of higher education" (Fink, 2003, p. 6).

\section{References}

Adams, D. M., \& Hamm, M. (1994). New designs for teaching and learning. San Francisco: Jossey-Bass.

Andresen, L., Boud, D., \& Cohen, R. (2000). Experience-based learning. In G. Foley (2 ${ }^{\text {nd }}$ ed.), Understanding adult education and training. Sydney: Allen \& Unwin.

Ash, S. L., \& Clayton, P. H. (2004). The articulated learning: An approach to guided reflection and assessment. Innovative Higher Education, 29(2), 137-154.

Ashley, G. C., \& Reiter-Palmon, R. (2012). Self-awareness and the evolution of leaders: The need for a better measure of self-awareness. Journal of Behavioral \& Applied Management, 14(1), 2-17.

Bialeschki, M. (2007). The three r's for experiential education researchers. Journal of Experiential Education, 29(3), 366-368.

Borasi, R., \& Rose, B. (1989). Journal writing and mathematics instruction. Educational Studies Mathematics, 20, 347-365.

Boud D., \& Walker, D. (1998). Promoting reflection in professional courses: The challenge of context. Studies in Higher Education, 23(2), 191-207.

Bowen, H. R. (1977). Investment in learning. San Francisco: Jossey-Bass.

Brain, C. (2002). The psychology of work. In Advanced psychology: Applications, issues, and Perspectives, 127-163. Cheltenham, UK: Nelson Thornes.

Buller, J. L. (2008). Creating a center for professional development and leadership. Academic Leader, 24, 6-8.

Burbach, M. E., Matkin, G. S., \& Fritz, S. M. (2004). Teaching critical thinking in an introductory leadership course utilizing active learning strategies: A confirmatory study. College Student Journal, 38, 482-493.

Carver, C. S. (1979). A cybernetic model of self-attention processes. Journal of Personality and Social Psychology, 37(8), 1255-1281.

Cisero, C. A. (2006). Does reflective journal writing improve course performance? College Teaching, 54(2), 231-236. 
Clough, G. W. (2008). Wanted: Well-rounded students who can think. The School Administrator, $65,28-32$.

Clyde, C. L., Walker, D. A., \& Floyd, D. L. (2005). An experiential learning program for Holocaust education. NASPA Journal, 42, 326-341.

Cook, I. (2000). "Nothing can ever be the case of 'us' and 'them' again": Exploring the politics of difference through border pedagogy and student journal writing. Journal of Geography in Higher Education, 24(1), 13.

Connaughton, S. L., Lawrence, F. L., \& Ruben, B. D. (2003). Leadership development as a systematic and multidisciplinary enterprise. Journal of Education for Business, 79(1), 46-51.

de Acosta, M. (1995). Journal writing in service learning: Lessons from a mentoring project. Michigan Journal of Community Service Learning, 2, 141-149.

Dewey, J. (1933). How we think: A restatement of the relation of reflective thinking to the educative process. New York: D. C. Heath.

Drohan, T., \& Murray, D. (2001). Responding to the "developing aerospace leaders" initiative: A master attack plan for reforming undergraduate professional development. Aerospace Power Journal, 15(2), 13.

Duval, S., \& Wicklund, R. A. (1972). A theory of objective self awareness. New York: Academic Press.

Farr, J. V., \& Brazil, D. M. (2009). Leadership skills development for engineers. Engineering Management Journal, 21(1), 3-8.

Fink, L. D. (2003). Creating significant learning experiences: An integrated approach to designing college courses. San Francisco: Jossey-Bass.

Garst, B., Scheider, I., \& Baker, D. (2001). Outdoor adventure program participation impacts on adolescent self-perception. Journal of Experiential Education, 24(1), 41.

Giddens, A. (1991). Modernity and self-identity: Self and society in the late modem age. Stanford, CA: Stanford University Press.

Goleman, D., Boyatzis, R., \& McKee, A. (2002). The emotional reality of teams. Journal of Organizational Excellence, 21(2), 55-65.

Grace, W., Ebbers, L., \& Kell, D. (1996). Values, Vision, Voice, Virtue: The 4 "V" model for ethical leadership development. In The Olympics of leadership: Overcoming obstacles, 
balancing skills, taking risks. Proceedings of the Annual International Conference of the National Community College Chair Academy, Phoenix, AZ, February 14-17, 1996. See JC 960276 [Washington, DC]: Distributed by ERIC Clearinghouse, 1996.

Harter, N. (2009). Critical thinking in groups. Journal of Leadership Education, 8, 111-117.

Henck, A., \& Hulme, E. (2008). Collaborative leadership through strengths development Part I: Self-awareness through strengths development. Academic Leader, 24(7), 1-1.

Hirsch, P., \& Lloyd, K. (2005). Real and virtual experiential learning on the Mekong: Field schools, e-sims and cultural challenge. Journal of Geography in Higher Education, 29(3), 321-337.

Itin, C. M. (1999). Reasserting the philosophy of experiential education as a vehicle for change in the 21st century. The Journal of Experiential Education, 22(2), 91-98.

Jiusto, S. S., \& Dibiasio, D. D. (2006). Experiential learning environments: Do they prepare our students to be self-directed, life-long learners? Journal of Engineering Education, 95(3), 195-204.

Johnson. D. W., \& Johnson, R. T. (2009). An educational psychology success story: Social interdependence theory and cooperative learning. Educational Researcher, 38, 365-379.

Jones, S., \& Brown, L. (1993). Alternative views on defining critical thinking through the nursing process. Holistic Nurse Practitioner, 7(3), 71-76.

Keeley, S. M., Ali, R., \& Gebing, T. (1998). Beyond the sponge model: encouraging Students' questioning skills in abnormal psychology. Teaching Of Psychology, 25(4), 270-274.

Knowles, M. S. (1978). The adult learner: A neglected species. Houston, TX: Gulf Publishing.

Kolb, D. A. (1984). Experiential learning: Experience as the source of learning and development. Englewood Cliffs, NJ: Prentice-Hall.

Lauer, R. (1990). Self-knowledge, critical thinking, and community should be the main objectives of general education. Chronicle of Higher Education, 36(20), B1-B3.

Leary, M. R., \& Buttermore, N. R. (2003). The evolution of the human self: tracing the natural history of self-awareness. Journal for the Theory of Social Behavior, 33, 365-404.

Levine, M. (2007). The essential cognitive backpack. Educational Leadership, 64(7), 16-22.

Lippitt, G. L. (1961). Leadership in action. Washington, DC: National Educational Association.

Mann, K., Gordon, J., \& MacLeod, A. (2009). Reflection and reflective practice in health 
professions education: a systematic review. Advances in Health Science Education, 14, 595-621.

Maslow, A. (1979). Humanistic education: Two articles by Abraham Maslow. Introduction by T. Phillips. Journal of Human Psychology, 19(3), 13-25.

McClam, T., Diambra, J. F., Burton, B., Fuss, A., \& Fudge, D. L. (2008). An analysis of a service-learning project: Students' expectations, concerns, and reflections. Journal of Experiential Education, 30(3), 236-249.

McClellan, R., \& Hyle, A. E. (2012). Experiential learning: Dissolving classroom and research borders. Journal of Experiential Education, 35(1), 238-252.

Mead, G. H. (1934). Mind, self and society from the standpoint of a social behaviorist. Chicago: The University of Chicago Press.

Meyers, C., \& Jones, T. B. (1993). Promoting active learning: Strategies for the college classroom. San Francisco: Jossey-Bass.

Miller, N. (2000). Learning from experience in adult education. In A. L. Wilson, \& E. R. Hayes (Eds.), Handbook of adult and continuing education, 71-86. San Francisco: Jossey-Bass.

Mills, R. (2008). "It's just a nuisance": Improving college student reflective journal writing. College Student Journal, 42(2), 684-690.

Mitchell, M. M., \& Poutiatine, A. L. (2001). Finding an experiential approach in graduate leadership curricula. Journal of Experiential Education, 24(3), 179-185.

Morrison, J. L., Rha, J., \& Helfman, A. (2003). Learning awareness, student engagement, and change: A transformation in leader development. Journal of Education for Business, $79(1), 11-17$.

Morton, K. (1993). Potential and practice for combining civic education and community service. In T. Kupiec (Ed.), Rethinking tradition: Integrating service with academic study on college campuses. Providence, RI: Campus Compact.

Morton, K., \& Campbell, J. (2007). Reflection. In J. Campbell, \& J. Hamerlinck (Eds.), Civic engagement in higher education: Reflection, power, evaluation, risk management, 7-39. St. Paul, MN: Minnesota Campus Compact.

Nelson Laird, T., Shoup, R., Kuh, G., \& Schwarz, M. J. (2008). The effects of discipline on deep approaches to student learning and college outcomes. Research in Higher Education, 49(6), 469-494. 
Nemeth, C., \& Owens, P. (1996). Making work groups more effective. The value of minority dissent. In M. A. West (Ed.), Handbook of work group psychology, 125-142. Chichester, England: John Wiley.

Nirenberg, J. (2003). Toward leadership education that matters. Journal of Education for Business, 79(1), 6-10.

Outward Bound (2013). Philosophy. Retrieved on January 24, 2013 from http://www.outwardbound.org/about-outward-bound/philosophy/

Parks, J. J., \& Millora, M. L. (2012). The relevance of reflection: An empirical examination of the role of reflection in the ethic of caring, leadership, and psychological well-being. Journal of College Student Development, 53, 221-242.

Priest, S., \& Gass, M. A. (1997) Effective leadership in adventure programming. Champaign, IL: Human Kinetics.

Rendón, L. (2009). Sentipensante (sensing/thinking) pedagogy. Sterling, VA: Stylus Publishing.

Roberts, C. (2008). Developing future leaders: The role of reflection in the classroom Journal of Leadership Education, 7, 116-130.

Schlanger, F., Lengfelder, J., \& Groves, D. (1999). An exploration of experiential education as an instructional methodology for travel and tourism. Education, 119(3), 480-488.

Schoel, J., Radcliffe, P., \& Prouty, P. (1989). Islands of healing: A guide to adventure-based counseling. Hamilton, MA: Project Adventure.

Schofield, J., \& Caragata, W. (1999). Learning on the front lines. Maclean's, 222(46), 90-95.

Schon, D. (1987). Educating the reflective practitioner: Toward a new design for teaching and learning in the professions. San Francisco: Jossey-Bass.

Shain, L., \& Farber, B. A. (1989). Female identity development and self-reflection in late adolescence. Adolescence, 24, 381-392.

Silverman, S. L., \& Casazza, M. E. (2000). Learning and development: Making connections to enhance teaching. San Francisco: Jossey-Bass.

Silvia, P. J., \& Duval, T. S. (2001). Objective self-awareness theory: Recent progress and enduring problems. Personality and Social Psychology Review, 5, 230-241.

Smith, D. G. (1977). College classroom interactions and critical thinking. Journal of Educational Psychology, 69(2), 180-190. 
Tannenbaum, R. S., \& Schmidt, W. H. (1958). How to choose a leadership pattern. Harvard Business Review, 36, 101-113.

Tsang, A. K. L. (2010). The Evolving Professional (EP) concept as a framework for the scholarship of teaching and learning. International Journal for the Scholarship of Teaching and Learning, 4(1). Retrieved in July 2010 from http://www.georgiasouthern.edu/ijsotl

Tsay, M., \& Brady, M. (2010). A case study of cooperative learning and communication pedagogy: Does working in teams make a difference? Journal of the Scholarship of Teaching and Learning, 10(2), 78-89.

Tsui, L. (1999). Courses and instruction affecting critical thinking. Research in Higher Education, 23, 421-441.

van Gelder, T. J. (2000). Learning to reason: A reason!- able approach. In C. Davis, T. J. van Gelder, \& R. Wales (Eds.), Cognitive Science in Australia, 2000: Proceedings of the Fifth Australasian Cognitive Science Society Conference. Adelaide: Causal.

Weierter, S. J. M. (1999). The role of self-awareness and self-monitoring in charismatic relationships. Journal of Applied Social Psychology, 29, 1246-1262.

West, C. (2012). Teaching leadership to undergraduates: Lessons from U.S. military colleges. Journal of College Teaching and Learning, 9, 135-146.

White, J. V. (2012). Students' perception of the role of reflection in leadership learning. Journal of Leadership Education, 11, 140-157.

Wicklund, R. A. (1975). Objective self-awareness. In L. Berkowitz (Ed.), Advances in experimental social psychology, 8, 233-275. New York: Academic Press.

Wicklund, R. A. (1978). Three years later. In L. Berkowitz (Ed.), Cognitive theories in social psychology, 509-521. New York: Academic Press.

Wood, J. T. (1977). The leader's brief: Teaching an adaptive approach to leading. Communication Education, 26(4), 354-358.

Wright, A. (1970). Participative education and the inevitable revolution. Journal of Creative Behaviour, 4, 234-282.

\section{Author Biography}

Dr. Denise Polk completed her doctorate at Kent State University). She is an interpersonal teacher-scholar focusing on close relationships. Her other primary area of study is conflict 
resolution, especially in the area of work-family integration. She teaches in the Honors College and currently serves as Graduate Coordinator for her department's graduate program. 